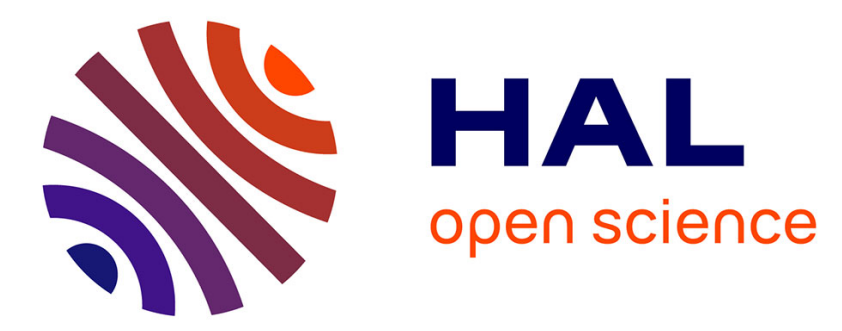

\title{
A Fluorescent False Neurotransmitter as a Dual Electrofluorescent Probe for Secretory Cell Models
}

Na Pan, Justine Pandard, Dina Ebene, Thomas Le Saux, Eric Aityahiatène, Xiaoqing Liu, Laurence Grimaud, Olivier O. Buriez, Eric Labbé, Frédéric Lemaître, et al.

\section{To cite this version:}

Na Pan, Justine Pandard, Dina Ebene, Thomas Le Saux, Eric Aityahiatène, et al.. A Fluorescent False Neurotransmitter as a Dual Electrofluorescent Probe for Secretory Cell Models. ChemPlusChem, 2019. hal-02997507

\section{HAL Id: hal-02997507 https://hal.science/hal-02997507}

Submitted on 10 Nov 2020

HAL is a multi-disciplinary open access archive for the deposit and dissemination of scientific research documents, whether they are published or not. The documents may come from teaching and research institutions in France or abroad, or from public or private research centers.
L'archive ouverte pluridisciplinaire HAL, est destinée au dépôt et à la diffusion de documents scientifiques de niveau recherche, publiés ou non, émanant des établissements d'enseignement et de recherche français ou étrangers, des laboratoires publics ou privés. 
Research Article for ChemPlusChem

J. Pandard et al.

\section{A Fluorescent False Neurotransmitter as a Dual Electrofluorescent Probe for Secretory Cell Models}

Ms. Justine Pandard, ${ }^{\mathrm{a}}$ Ms. Na Pan, ${ }^{\mathrm{b}}$ Ms. Dina H. Ebene, ${ }^{\mathrm{a}}$ Dr. Thomas Le Saux, ${ }^{\mathrm{a}}$ Mr. Eric AitYahiatène, ${ }^{\mathrm{a}}$ Dr. Xiaoqing Liu, ${ }^{\mathrm{a}}$ Dr. Laurence Grimaud, ${ }^{\mathrm{b}}$ Dr. Olivier Buriez, ${ }^{\mathrm{a}}$ Pr. Eric Labbé, ${ }^{\mathrm{a}}$ Dr. Frédéric Lemaître, $^{\mathrm{a}^{*}}$ Dr. Manon Guille-Collignon ${ }^{\mathrm{a}^{*}}$

a) PASTEUR, Département de Chimie, Ecole Normale Supérieure, PSL University, Sorbonne Université, CNRS, 75005 Paris, France.

b) Laboratoire de biomolécules (LBM), Département de chimie, Sorbonne Université, École normale supérieure, PSL University, Sorbonne Université, CNRS, 75005 Paris,

Number of figures: 7 


\begin{abstract}
In this work, a new dual electrofluorescent probe (FFN42) belonging to Fluorescent False Neurotransmitter family was rationally designed for investigating cell secretion. This coumarin including one amino and two hydroxy groups is very promising due to its electroactive and fluorescent properties. The optimal excitation and emission wavelengths $(380 \mathrm{~nm}$ and $470 \mathrm{~nm}$ respectively) make this probe adapted to its use in fluorescence microscopy. Photophysical properties of FFN42 were investigated by means of UV/Vis absorption and fluorescence spectroscopies and gave access to quantum yield (0.18), molar absorption coefficient $\left(12000 \mathrm{M}^{-}\right.$ ${ }^{1} . \mathrm{cm}^{-1}$ ) and pKas (5.4 and 6.7 for hydroxy groups). Electroactivity of FFN42 was investigated on carbon fiber and ITO electrodes at relatively low oxidation potentials $(0.24 \mathrm{~V}$ and $0.45 \mathrm{~V}$ vs $\mathrm{Ag} / \mathrm{AgCl}$ respectively). Epifluorescence observations evidenced that FFN42 was accumulated into secretory vesicles of PC12 and N13 cells. Toxicity tests further revealed that FFN42 had no lethal effect on these cells. Amperometric data obtained on carbon fiber electrodes proved that the probe is released by N13 cells. As a consequence, this bimodal probe opens new fields in the investigation of biological applications of secretion with electrofluorescent probes.
\end{abstract}




\section{Introduction}

Communication between cells is a fundamental process involved in numerous normal healthful and pathologic functioning phenomena. In this respect, vesicular exocytosis is a ubiquitous pathway of intercellular communication where an emitting cell delivers water soluble molecules contained in secretory granules. This process notably occurs during synaptic transmission and hormone secretion. ${ }^{[1]}$ Briefly, an intracellular vesicle moves to the cell membrane through vesicle-trafficking steps via cytoskeleton network (actin, microtubule and motor proteins) to reach the cell membrane. Steps of vesicles tethering and docking then occur and aim at maintaining the vesicle at the close vicinity of the cell membrane thanks to proteic anchors. ${ }^{[2]}$ Vesicular fusion with cell membrane begins with the merging of the two membranes before the subsequent formation of a narrow fusion pore $(\sim \mathrm{nm})$ through which the first encapsulated biomolecules start to diffuse. A more massive release of biochemical molecules can be then achieved via the consecutive melting of the granule with the plasma membrane. ${ }^{[3]}$

Electrochemistry and fluorescence techniques are the most widely employed techniques for investing exocytosis in real time at the single cell level. Fluorescent microscopies are based on the use of fluorescent markers (FM 1-43, acridine orange, GFP...) that can be located in the secretory vesicles (membrane, vesicular content...). As a consequence, the secretory vesicles that undergo fusion can be imaged in real time and this monitoring gives access to the status of the vesicles before and during fusion (displacements, fusion location...). Among fluorescence imaging techniques, total internal reflection fluorescence microscopy (TIRFM) is particularly adapted. An induced evanescent wave at the bottom of an adherent biological sample confines the excitation to a tiny thickness in the close vicinity of the cell membrane. This avoids the background fluorescence from non-focal planes and enhances the signal/noise ratio and the axial resolution. For example, fluorescent-labelled vesicles within an adherent cultured cell on a microscope coverslip can be imaged in a region typically less than $150 \mathrm{~nm}$ thick. The mapping of secretory sites on cell surface or the tracking of vesicles can then be observed. Conversely, amperometry gathers quantitative information on the amount of electroactive species released with an excellent temporal resolution $(\sim \mathrm{ms})$ that perfectly meets the requirement of the fast kinetics of exocytosis. Indeed, many biogenic endogenous monoamine neuromolecules (serotonin, dopamine, norepinephrine, epinephrine; Figure S1) are electroactive species. Their oxidation at a 
microelectrode surface located in the close vicinity of a single cell results in an electrical current that features the release dynamics. ${ }^{[4]}$ Adding fluorescence measurements is thus an important improvement of the electrochemical technique. It thus would combine the excellent temporal resolution of amperometry with the location of individual exocytotic events, thus offering the possibility to monitor whole exocytotic events. ${ }^{[5]}$

This is why we recently implemented a new combining strategy that gathers both analytical techniques to study exocytosis on specific transparent ITO (Indium Tin Oxide) microchips that allowed the simultaneous monitoring of the vesicular release by amperometry and fluorescence. As a proof of concept, the dual detection was demonstrated with a stable clone of enterochromaffin BON cells (BC21) that expresses GFP-tagged neuropeptide-Y (NPY-GFP) and release the electroactive serotonin. ${ }^{[5 b, 6]}$ However, the use of two independent probes (fluorescent and electroactive) prevented a quantitative analysis of the release due to a lack of control on the relative proportion of both probes within vesicles (simultaneous optical and electrochemical signals reached only $20 \%$ ). A unique dual electrofluorescent probe, FFN102, was then introduced. This probe belongs to the family of fluorescent false neurotransmitter (FFN), i.e. a synthesized analogue of a biogenic neurotransmitters initially proposed as a versatile synaptic imaging platforms. ${ }^{[7]}$ Indeed, FFN102 was shown to be electroactive on ITO and carbon electrodes as well as recognized by VMAT (vesicular monoamine transporter which carries monoamine neurotransmitters from the cytoplasm into synaptic vesicles) of BON N13 and PC12 cells. $^{[5 c, 5 \mathrm{~d}, 8]}$ However, its high oxidation potential (+900 $\mathrm{mV}$ vs $\mathrm{Ag} / \mathrm{AgCl}$ on ITO) induces electrical noise on the ITO semiconductor material that restricts its advantages. ${ }^{[5 \mathrm{c}]}$ In this work, we report on an innovative dual electrofluorescent probe called FFN42 capable of acting as optical/electrochemical dual reporter in the coupling method, ${ }^{[5]}$ especially with longer excitation/emission wavelengths and/or lower oxidation potential. This approach could be of high interest to counterbalance the drawbacks of FFN102. In this way, the bimodal probe FFN42 was designed and characterized by electrochemistry, photophysics and with biological tests of uptake/toxicity and ability to be released, thus showing it compensates defaults of previous dual probes of FFN family like FFN102 for the purpose of the coupling technology (amperometryTIRFM). 


\section{Results and discussion}

\subsection{Photophysical properties of FFN42}

Photophysical properties of FFN42 (Figure 1A) were firstly investigated. Under physiological conditions ( $\mathrm{pH}$ 7.4), optimal excitation and emission wavelengths were $380 \mathrm{~nm}$ and $470 \mathrm{~nm}$, respectively (Figure 1B). In the case of FFN102 (SI Figure S1), optimal excitation and emission wavelengths were located at $371 \mathrm{~nm}$ and $456 \mathrm{~nm}$, respectively. Thus, the value of maximum excitation wavelength of FFN42 is red shifted for $9 \mathrm{~nm}$ (see SI Figure S3) ${ }^{[9]}$ Beyond this slight increase, using FFN42 rather than FFN102 globally shows advantages in terms of fluorescence. At $405 \mathrm{~nm}$ excitation wavelength (commonly available in microscopy setups), fluorescence of FFN102 only reached 25\% of the normalized fluorescence intensity (Figure S3). Conversely, 95\% of the normalized intensity is reached for FFN42 due to its broader absorption spectrum (Figure 1B). Furthermore, fluorescence intensity significantly augments with the rise of $\mathrm{pH}$ values, especially from $\mathrm{pH} 6$ to $\mathrm{pH} 7.4$ where the emission intensity increases by a factor 13 (Figure 1C). Considering the difference of $\mathrm{pH}$ between the intravesicular $(\mathrm{pH}$ 5 6) and extracellular media ( $\mathrm{pH}$ 7.4), this $\mathrm{pH}$-dependence is fully consistent with the required properties of a fluorescent probe for investigating exocytosis. ${ }^{[10]}$ Checking the validity of Beer-Lambert's law with UV/Vis absorption spectra (Figure 1D) gave access to the molar absorption coefficient $\varepsilon$ of FFN42 $\left(12000 \mathrm{M}^{-1} \cdot \mathrm{cm}^{-1}\right.$ in a mixture of acetonitrile/phosphate buffer $\left.(50 / 50 \mathrm{v} / \mathrm{v})\right)$ at $380 \mathrm{~nm}$. This value is comparable to $\varepsilon$ values of the coumarin nucleus at $311 \mathrm{~nm}$ in ethanol $\left(5700 \mathrm{M}^{-1} . \mathrm{cm}^{-1}\right)$ and umbelliferone (see structures in Figure S1) at $330 \mathrm{~nm}$ in ethanol (evaluated at $16800 \mathrm{M}^{-1} \cdot \mathrm{cm}^{-1}$ ). ${ }^{[1]}$ Fluorescence spectrum of FFN42 and of the quinone sulfate reference gave access to FFN42 quantum yield as mentioned in the equation (1) and a value of 0.18 was found for the fluorescence quantum yield of FFN42. ${ }^{[12]}$ The brightness of FFN42 allowed fluorescence imaging with good signal to noise ratio (see below).

As described above, the absorption, excitation, and emission spectra of FFN42 are pH-dependent. This can be rationalized by the equilibrium between the protonated (phenol) and deprotonated (phenolate) forms in accordance with previous publications. ${ }^{[7]}$ In the case of FFN42, pKas of the three acid functions (hydroxy groups in positions 6 and 7 respectively; amino group in position 4) were determined by acquisition of $32 \mathrm{UV}$-vis absorption spectra at different $\mathrm{pH}$ values lying between 3.57 and 11.05 . Values were 9.8 for the primary amine (which refers to the ammonium 
ion/amine couple) in position 4, 6.7 for the hydroxy group in position 6 and 5.4 for the hydroxy group in position 7 (Figure 1A). ${ }^{[13]}$ The value for the amino group is consistent with similar structures (for instance, $\mathrm{pKa}=9.83$ for phenethylamine ${ }^{[14]}$ ). Furthermore, the $\mathrm{pH}$-dependence of fluorescence for FFN42 is in agreement with its moderately acidic pKas of 5.4 and 6.7 for the two phenol functions. Indeed, at physiological $\mathrm{pH}$, the concentration of the phenolate forms of the probe is significantly high to enhance the fluorescence level. Of note, the use of $\mathrm{pH}$ dependent probes for detection of exocytosis cell secretion avoids any confusion between the vesicular release and a return of the marked vesicle in the cytoplasm.

All in all, the optical properties (slight increase in maximum wavelength and quite broad absorption band) make FFN42 more suitable than FFN102 for fluorescence measurements.

\subsection{Electrochemical properties of FFN42}

The electrochemical behaviour of FFN42 was studied by cyclic voltammetry with a carbon fiber electrode (CFE; $10 \mu \mathrm{m}$ diameter) between -0.2 and $0.8 \mathrm{~V}$ vs $\mathrm{Ag} / \mathrm{AgCl}$ or an Indium Tin Oxide (ITO) microdevice (disk of $150 \mu \mathrm{m}$ diameter) between 0.0 and $0.6 \mathrm{~V}$ vs $\mathrm{Ag} / \mathrm{AgCl}$ (scan rate $=$ $200 \mathrm{mV} \cdot \mathrm{s}^{-1}$ ). As shown in Figure 2A and 2B, FFN42 is electroactive at relatively low potential on carbon fiber (oxidation peak at $0.24 \mathrm{~V}$ vs $\mathrm{Ag} / \mathrm{AgCl}$ ) and ITO (oxidation peak at $0.45 \mathrm{~V}$ vs $\mathrm{Ag} / \mathrm{AgCl}$ ) microelectrodes. Others endogenous neurotransmitters (dopamine, serotonin; see Figure S1) or dual electrofluorescent FFN probe like FFN102 are also electroactive. As for this kind of compounds, passivation of electrode surface was observed with FFN42 (see Figure S4). ${ }^{[5 c]}$ Nevertheless, such a fouling does not jeopardize the use of FFN42 in electrochemical monitoring of secretion at the cell level with amperometry since cyclic voltammetry conditions differ in terms of conditions (non-dynamic solution, different spatial and temporal scales...). As an example, dopamine and serotonin are two commonly neurotransmitters studied in amperometry though they show high passivation of the working electrodes in cyclic voltammetry. ${ }^{[15]}$ Compared to FFN102, the detection of FFN42 on carbon and ITO surfaces at less anodic potentials is very likely due to the replacement of the chlorine group by a second hydroxy group in position 6 of the coumarin nucleus. This more electron-donating group is expected to promote easier oxidation. This low oxidation potential value will decrease the applied potential in amperometry and thus the electrical noise namely due to capacitive phenomena. This 
also does not limit the cell lines to "empty" cell models of neurotransmitters. This potential diversity of the biological object of study is of great importance, the properties of exocytosis being strongly dependent on the cellular model. ${ }^{[3]}$

Further analyses require investigating of the FFN42 oxidation mechanism. Owing to its catecholbased structure, a $2 \mathrm{e}^{-} / 2 \mathrm{H}^{+}$mechanism is expected. The number of electrons exchanged during the oxidation can be estimated from two independent electrochemical measurements that helps to calculate unknown parameters (diffusion coefficient " $\mathrm{D}$ " and the number of electrons " $\mathrm{n}$ " involved in the process of type $\mathrm{Ox}+\mathrm{ne}^{-}=\mathrm{Red}$ ) from controlled parameters (concentration, electrode surface, scan rate...). In practice, a transient (cyclic voltammetry on a static millimeter electrode) and a steady state technique (rotating disk electrode ; RDE) are associated. ${ }^{[16]}$ On the one hand, in cyclic voltammetry, the magnitude of the current spike is expressed by the RandlesSevcik's law for a diffusion controlled process : ${ }^{[17]}$

$$
\mathrm{i}=0.446 \mathrm{nFAC} * \mathrm{D}^{1 / 2}\left(\frac{\mathrm{nFv}}{\mathrm{RT}}\right)^{1 / 2}=268604 \mathrm{n}^{3 / 2} \mathrm{AC}^{*} \mathrm{D}^{1 / 2} \mathrm{v}^{1 / 2} \text { at } 25^{\circ} \mathrm{C}
$$

with $\mathrm{A}$ is the electrode surface area $\left(\mathrm{cm}^{2}\right)$, D the diffusion coefficient $\left(\mathrm{cm}^{2} \cdot \mathrm{s}^{-1}\right), \mathrm{C}^{*}$ the electroactive species concentration $\left(\mathrm{mol} . \mathrm{cm}^{-3}\right), \mathrm{v}$ the scan rate $\left(\mathrm{V} \cdot \mathrm{s}^{-1}\right)$ and $\mathrm{F}=96500 \mathrm{C} \cdot \mathrm{mol}^{-1}$.

On the other hand, experiments with a RDE lead to a steady state current that can be expressed according to Levich equation:

$$
\mathrm{i}=0.62 \mathrm{nFA} \omega^{1 / 2} v^{-1 / 6} \mathrm{D}^{2 / 3} \mathrm{C}^{*}
$$

where $\omega$ is the angular rotation rate of the electrode $\left(\operatorname{rad} . \mathrm{s}^{-1}\right)$ and $v$ is the kinematic viscosity $(v=$ $10^{-6} \mathrm{~cm}^{2} \cdot \mathrm{s}^{-1}$ for water).

The values of " $n$ " and "D" can then be deduced by combining equations (2) and (3) and measurements of the effects of " $v$ " and " $\omega$ ". The number of electrons exchanged during the oxidation process was found equal to $n=2.01$ and the diffusion coefficient of FFN42 was estimated at $\mathrm{D}=1.99 .10^{-5} \mathrm{~cm}^{2} \cdot \mathrm{s}^{-1}$, a value comparable to the one of dopamine $\left(\mathrm{D}=0.9 \cdot 10^{-5} \mathrm{~cm}^{2} . \mathrm{s}^{-}\right.$ ${ }^{1}$ on carbon fiber electrodes). ${ }^{[18]}$ The knowledge of " $n$ " is an essential parameter that allows one to calculate the amount or released molecules (Faraday's law) during the analysis of exocytotic signals in amperometry. ${ }^{[3]}$ 
Investigation of $\mathrm{pH}$ influence on cyclic voltammograms (CVs) was then carried out in PBS over a $\mathrm{pH}$ range of 4.1 to 8.4 with a carbon fiber electrode $\left(\mathrm{CFE} ;\right.$ scan rate $\left.=200 \mathrm{mV} . \mathrm{s}^{-1}\right)$. As displayed in Figure 2C, the FFN42 oxidation peak shifted to less anodic potential values when pH value increased. This result suggests that the oxidation of FFN42 probably involves the two hydroxy groups due to the formation of deprotonated phenolate forms at higher $\mathrm{pH}$ values which are easier to oxidize. Furthermore, the $\mathrm{E}_{\mathrm{p}}=\mathrm{f}(\mathrm{pH})$ graph shows a straight line $($ Figure 2D, slope $=43 \mathrm{mV})$. In a general case (for a reversible process of the type $\mathrm{Ox}+\mathrm{mH}^{+}+\mathrm{ne}^{-}=\mathrm{Red}$ ), the expected slope is expressed according to: ${ }^{[19]}$

$$
\frac{\partial \mathrm{E}_{\mathrm{p}, \mathrm{a}}}{\partial \mathrm{pH}}=-2.3 \frac{\mathrm{mRT}}{\mathrm{nF}} \sim-59 \frac{\mathrm{m}}{\mathrm{n}}(\mathrm{mV}) \quad \text { at } 25^{\circ} \mathrm{C}
$$

This is indeed the case for FFN102 (Figure S5) where the slope $(58.5 \mathrm{mV} \sim 59 \mathrm{mV}$ ) is consistent with a phenol function involved in a rate-determining CE (Chemical-Electrochemical) process where $\mathrm{m}=\mathrm{n}=1$. Conversely, FFN42 did not give the expected slope of $59 \mathrm{mV}(\mathrm{m}=\mathrm{n}=2)$. This result is not unusual for benzenes bearing hydroxy groups like quinols ${ }^{[20]}$ and was especially evidenced in recent electrochemical studies of catechol (Figure S1). ${ }^{[21]}$ In the latter case, theoretical and experimental analyses evidenced that, despite a whole $2 \mathrm{e}^{-} / 2 \mathrm{H}^{+}$mechanism, the catechol oxidation mechanism within a theoretical nine-species square scheme (including a oneelectron irreversible step) could account for different slopes ranging from 40 to $59 \mathrm{mV}$ as a function of $\mathrm{pH}$. However, contrary to catechol ( $\mathrm{pKas}=9.5$ and 12.8 respectively), the two $\mathrm{pKa}$ values for FFN42 (5.4 and 6.7 respectively) are too close to afford a strong predominance of acidic/basic forms of FFN42 over the $\mathrm{pH}$ values investigated here. It thus results in an average behavior leading to the straight line displayed in Figure 2D. As a consequence, the general mechanism for the oxidation of FFN42 is probably similar to the one depicted for catechol, i.e. a full $2 \mathrm{e}^{-} / 2 \mathrm{H}^{+}$process described by a square scheme (Figure 3 ).

\subsection{Uptake of FFN42 within secretory vesicles of cell models of exocytosis}

We firstly used N13 cells that are a stable clone of BON cells to check the ability of FFN42 to penetrate the cytoplasm and then the secretory vesicles of the cells. BON cells derived from a 
carcinoid tumor and have been shown considerable attraction for their use as cellular model for exocytotic studies ${ }^{[22]}$ although they need to be loaded with exogenous serotonin ${ }^{[23]}$ or FFN102 to detect secretion by amperometry and GFP or FFN102 for TIRFM analysis. ${ }^{[5 \mathrm{c}, 5 \mathrm{~d}, 8]}$ The uptake and distribution of FFN42 in BON N13 were analyzed by epifluorescence. Figure 4 shows the effects of the FFN42 concentration and incubation time. Before observation, cells were rinsed three times and analyzed in PBS ( $\mathrm{pH}$ 7.4). Images shown in Figure 4 indicate that the minimal concentration of FFN42 to observe clear visible dots in the cell corresponding to exocytotic granules is $20 \mu \mathrm{M}$. Kinetic incubation tests showed that an incubation time of $20 \mathrm{~min}$ is the optimal one for vesicular penetration of FFN42 in vesicles. No differences in terms of fluorescence intensity were seen from 20 to $60 \mathrm{~min}$ of incubation and the percentage of cells with fluorescent vesicles was independent of the exposure time with FFN42 (value ranging between 10 and 50\%). These results are consistent with the ability of several FFNs to globally mimic the intrinsic properties of monoamine neurotransmitters and to be transported by VMATs (vesicular monoamine transporter), ${ }^{[7 \mathrm{~b}, 24]}$ whose both isoforms are expressed by BON cells. ${ }^{[25]}$

Finally, vesicular uptake of FFN42 within vesicles from PC12 cells was also investigated in order to ascertain on another well-known and used secretory cell model for exocytosis (Figure 5). The effects of FFN42 concentration and incubation time were analyzed with the same protocol than for N13 cells. It is worth mentioning that PC12 cells have smaller secretory vesicles by comparison with $\mathrm{N} 13$ cells (typically $75-120 \mathrm{~nm}$ radius) ${ }^{[26]}$ making it more difficult for the identification of individual secretion vesicles. Nevertheless, fluorescence was observed in PC12 cells at optimal conditions of $20 \mu \mathrm{M}$ of FFN42 during 30 min with observation of blurry dots. The percentage of cells with fluorescence staining in PC12 cells loaded with FFN42 was around 60$70 \%$. As a result, this shows that FFN42 can be uptaken in the vesicles of two usual cell models of exocytosis.

\subsection{Cellular toxicity tests}

A very important issue is that the electrofluorescent probe FFN42 did not lead to toxic effects. As described above, BON N13 cells were incubated with a $20 \mu \mathrm{M}$ solution of FFN42 for a period of 20 min that were the optimal vesicular internalization conditions previously determined. Toxicity 
tests were achieved (see experimental part) by using a solution of $1 \mu \mathrm{M}$ of Calcein and $1 \mu \mathrm{M}$ of Ethidium Homodimer (from the LIVE / DEAD-Thermofischer Scientific kit) in PBS (pH 7.4). Cell samples were rinsed with a solution of filtered PBS ( $\mathrm{pH} \mathrm{7.4),} \mathrm{before} \mathrm{their} \mathrm{observation} \mathrm{and}$ further analyzed in this same solution. No dead (red) cells were observed on the whole set of experiments achieved under the best conditions of FFN42 uptake by BON N13 cells (Figure 6). The same observation was obtained under control conditions (i.e. incubation with a solution without FFN42 during $20 \mathrm{~min}$; data not shown). This experiment confirmed the non-toxicity of FFN42 as a fluorescent and electrochemical reporter in BON N13 cells at the tested concentrations.

\subsection{Amperometry measurements of FFN42 exocytotic release}

Beyond the investigations detailed above, it is important to demonstrate that the uptaken FFN42 molecule within vesicles can be released by the considered cells. This can be achieved by amperometry at CFE. The CFE is positioned in the close vicinity of a given BON N13 single cell previously incubated with FFN42 (see experimental part). After helding the CFE potential at 500 $\mathrm{mV}$ vs $\mathrm{Ag} / \mathrm{AgCl}$ and stimulating the cell with ionomycin to trigger exocytosis, a chronoamperogramm is recorded (Figure 7). This corresponds to a usual electrochemical monitoring of exocytosis at the single cell level where each current spike reflects the release of the electroactive content of an individual vesicle. ${ }^{[3]}$ Because no electroactive content can be detected at $+500 \mathrm{mV}$ vs $\mathrm{Ag} / \mathrm{AgCl}$ from no pre-loaded $\mathrm{BON} \mathrm{N13}$ cells, ${ }^{[5 \mathrm{c}, 25 \mathrm{c}]}$ the spikes necessarily result from the oxidation of FFN42 at the electrode surface that shows the ability of N13 cells to release the previously loaded FFN. Preliminary statistics were performed to calculate the exocytotic frequency $(0.16 \pm 0.02 \mathrm{~Hz})$ which is relatively low and consistent with this cell model. ${ }^{[25 c]}$ Furthermore, the mean parameters of amperometric spikes $(n=24)$ were estimated to : $\mathrm{t}_{1 / 2}=(26.0 \pm 1.9) \mathrm{ms} ; \mathrm{Q}=(421 \pm 55) \mathrm{fC} ; \mathrm{I}_{\max }=(9.6 \pm 1.3) \mathrm{pA}$. It is interesting to compare these data with those obtained with serotonin-loaded or FFN102-loaded vesicles of N13 cells $\left(\right.$ serotonin $: \mathrm{t}_{1 / 2}=(32.0 \pm 0.5) \mathrm{ms} ; \mathrm{Q}=(182 \pm 11) \mathrm{fC} ; \mathrm{I}_{\max }=(4.9 \pm 0.5) \mathrm{pA} ; \mathrm{FFN102}: \mathrm{t}_{1 / 2}=$ $\left.(30.2 \pm 1.2) \mathrm{ms} ; \mathrm{Q}=(209 \pm 15) \mathrm{fC} ; \mathrm{I}_{\max }=(5.3 \pm 0.5) \mathrm{pA}\right) .{ }^{[5 \mathrm{~d}, 25 \mathrm{c}]}$ Whereas the duration of a vesicular event is expectedly similar for all, the amount of electroactive probe as well as the flux is significantly higher for FFN42. This is probably related to a less efficient serotonin loading ${ }^{[25 c]}$ 
and a one-electron oxidation for FFN102 while FFN42 oxidation involves a two-electron process (see above). In any event, this also evidenced that the magnitude of the amperometrical signals resulted from the FFN42 is higher thus significantly enhancing the signal/ratio of the electrochemical detection.

\section{Conclusion}

In this work, we reported on the photophysical and electrochemical properties of a promising dual probe FFN42 for the analysis of exocytosis with coupling optical/electrochemical method. We show here that FFN42 presents key advantages compared to the previously used FFN102, like a lower oxidation potential on carbon and ITO and also a chemical formula, steric hindrance and diffusion coefficient very closed to the endogenous neurotransmitters. This new synthesized dual electrofluorescent probe also possesses interesting photophysical properties as well as ability to be recognized and uptaken in vesicles of BON N13 and PC12 cells and secreted by BON cells, that make it an ideal candidate for labeling secretory vesicles in fluorescence and electrochemistry.-Future prospective works will focus on FFN42 potential use on coupled amperometric and TIRFM recordings on cells to provide a deeper understanding of the fluorescent optical signals in cells secretion thanks to the support of amperometric detection.

\section{Experimental section}

\section{Synthesis}<smiles>COC(=O)CC(=O)CCNC(=O)OCc1ccccc1</smiles>

The starting substrate Boc- $\beta$-Ala-OH (1.00g, $5.28 \mathrm{mmol}, 1.0$ equiv) was added into a suspension of fresh 1,1'-carbonyldiimidazole (1.03 g, $11.63 \mathrm{mmol}, 2.2$ equiv) in distilled THF (15 mL) under Argon. The resulting suspension was stirred for 4 hours. $\mathrm{MgCl}_{2}$ (503 mg, $5.28 \mathrm{mmol}$, 1.0 equiv) and methyl potassium malonate $(1.65 \mathrm{~g}, 10.6 \mathrm{mmol}, 2.0$ equiv) were added under Argon. The resulting solution was stirred vigorously overnight before $\mathrm{H}_{2} \mathrm{O}(15 \mathrm{~mL})$ and a $1 \mathrm{M}$ aqueous $\mathrm{HCl}$ 
solution $(10 \mathrm{~mL})$ were added. The aqueous phase was extracted with ethyl acetate $(30 \mathrm{~mL} * 3)$. The collected organic phase was successively washed with a $1 \mathrm{M}$ aqueous $\mathrm{HCl}$ solution $(10 \mathrm{~mL})$ and brine $(8 \mathrm{~mL})$, dried with anhydrous $\mathrm{MgSO}_{4}$, filtered, and concentrated under reduced pressure to give the product 1 as a light-yellow liquid (657 mg, 51\%). ${ }^{1} \mathrm{H}-\mathrm{NMR}\left(300 \mathrm{MHz}, \mathrm{CDCl}_{3}\right)$ $\delta$ (ppm): 4.96 (brs, $1 \mathrm{H}, \mathrm{NH}$ ), 3.74 (s, $3 \mathrm{H}, \mathrm{CH}_{3}$ ), 3.46 (s, 2H, $\mathrm{CH}_{2}$ ), 3.37 (q, $J=5.9 \mathrm{~Hz}, 2 \mathrm{H}, \mathrm{CH}_{2}$ ), $2.77\left(\mathrm{t}, J=5.9 \mathrm{~Hz}, 2 \mathrm{H}, \mathrm{CH}_{2}\right), 1.42(\mathrm{~s}, 9 \mathrm{H}, t \mathrm{Bu}) .{ }^{13} \mathrm{C}-\mathrm{NMR}\left(75 \mathrm{MHz}, \mathrm{CDCl}_{3}\right) \delta(\mathrm{ppm}): 202.5$, $167.4,156.0,79.6,52.6,49.2,43.2,35.1,28.5$.

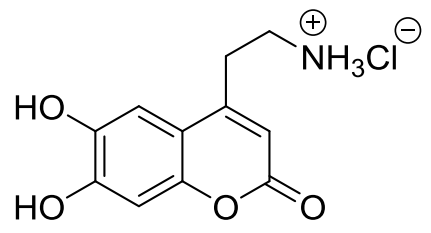

\section{FFN42}

To a mixture of 1, 2, 4-trihydroxybenzene (164 mg, $1.30 \mathrm{mmol}$, 1.3equiv) and product 1 ( $245 \mathrm{mg}$, $1.00 \mathrm{mmol}, 1.0$ equiv) was added methanesulfonic acid $(0.65 \mathrm{~mL}, 10.00 \mathrm{mmol}, 10.0$ equiv) at $0{ }^{\circ} \mathrm{C}$. The resulting mixture was stirred for 3 hours at room temperature before dilution with cold ethyl ether $(10 \mathrm{~mL})$. The residual solid was filtered off, washed with cold diethyl ether and recrystallized with $0.1 \mathrm{M}$ aqueous $\mathrm{HCl}$ solution to give the desire product as a pale grey solid (FFN42) (191 mg, 74\%). ${ }^{1} \mathrm{H}-\mathrm{NMR}\left(300 \mathrm{MHz}, \mathrm{DMSO}-d^{6}\right) \delta$ (ppm) : 10.49 (br s, 1H, OH), 9.34 (br s, 1H, OH), 7.83 (br s, 3H, NH 3 ), 7.09 (s, 1H, Har), 6.77 (s, 1H, Har), 6.14 (s, 1H, Har), 3.13 (dd, $\left.J=12.4 \mathrm{~Hz}, 6.9 \mathrm{~Hz}, 2 \mathrm{H}, \mathrm{CH}_{2}\right), 2.97\left(\mathrm{t}, J=6.9 \mathrm{~Hz}, 2 \mathrm{H}, \mathrm{CH}_{2}\right) .{ }^{13} \mathrm{C}-\mathrm{NMR}\left(75 \mathrm{MHz}\right.$, DMSO- $d^{6}$ ) $\delta(\mathrm{ppm}): 160.6,151.7,150.5,148.2,143.1,111.2,110.5,109.3,103.0,37.4,29.1$.

\section{Chemicals}

All buffer solutions were made using ultrapure water from a Millipore purification system (resistivity of $18.2 \mathrm{M} \Omega \mathrm{cm}$ at $25{ }^{\circ} \mathrm{C}$ ). Unless stated, all the chemicals (analytical grade) were obtained from Sigma-Aldrich. The Locke's $\times 1$ physiological saline $(\mathrm{pH}$ 7.4) was used as buffer. It was diluted 10 times from Locke'sX10 mother solution ( $\mathrm{pH}$ 7.4) composed of $56 \mathrm{mM}$ glucose, $1540 \mathrm{mM} \mathrm{NaCl}, 56 \mathrm{mM} \mathrm{KCl}, 50 \mathrm{mM}$ Hepes, $36 \mathrm{mM} \mathrm{NaHCO}$. The PBS (Phosphate buffered saline composed by $140 \mathrm{mM} \mathrm{NaCl}, 10 \mathrm{mM} \mathrm{Na} 2 \mathrm{HPO}_{4}, 2.68 \mathrm{mM} \mathrm{KCl}, \mathrm{pH}$ 7.4) was prepared by 
dissolving tablets (Ref. 18912, ThermoFisher Scientific) in water. $10 \mu \mathrm{M}$ ionomycin stimulation solution for amperometric experiments on N13 cells loaded with FFN42 was diluted from $1 \mathrm{mM}$ mother solution in DMSO (Sigma-Aldrich) with Locke's $\times 1$ physiological saline supplemented with $2.5 \mathrm{mM} \mathrm{CaCl}_{2}$ and $1.2 \mathrm{mM} \mathrm{MgCl} 2$.

\section{Fabrication of carbon fiber electrodes}

All CFEs (carbon fiber electrodes) were fabricated by sealing individual carbon fibers into pulled-glass capillaries. First, individual carbon fibers were aspirated $(10-\mu \mathrm{m}$ diameter, Thornel P-55S, Cytec) into glass capillary tubing (PG120T-10-Harvard Apparatus 1.2mm O.D x 0.93mm I.D), then through a vertical micropuller (PC-100; Narishige), the capillary was separated into two identical tubes with a short length of protruding carbon fiber at the tapered end. A drop of mercury or Galinstan (mix of Galium, Indium and Tin, Geratherm Medical AG, Germany) was back-filled into the capillary tubes to make an electrical contact. In order to limit a specific working area at the top of the carbon fiber, an insulating layer of poly(oxyphenylene) was electrochemically deposited carbon fiber according to a published method. ${ }^{[27]}$ A mixed solution containing $0.40 \mathrm{M}$ allylamine, 0.23 M 2-allylphenol, and 0.23 M 2-butoxyethanol in 1:1 (v/v) water-methanol was used. To achieve polymer deposition, a potential of $+4 \mathrm{~V}$ was applied to carbon fiber electrode for 3 min with a platinum counter electrode. After being washed within distilled water, the polymer insulated electrodes were cured for $3 \mathrm{~h}$ at $150{ }^{\circ} \mathrm{C}$ in order to completely remove the solvent. To perform electrochemical experiments, polymer insulated carbon fiber tip was cut to an appropriate length and was polished on a diamond particle whetstone microgrinder (EG-4; Narishige) at an angle of $45^{\circ}$ for 2 min to produce an elliptical and conductive surface. Nichrome wire was finally inserted into conductive mercury to make an electrical contact.

\section{Fabrication of ITO microdevices}

In order to define the electrode surface on circular glass substrate $(170 \mu \mathrm{m}$ in thickness and $4 \mathrm{~cm}$ in diameter, Thermo Scientific), a lithography step with a positive photosensitive resin AZ5214-E (Microchemicals) was used and deposited by spin-coating. A Ti-Primer was used in order to 
provide a better adhesion of the resin on glass. Glass substrates underwent an annealing step for a period of two minutes at a temperature of $110^{\circ} \mathrm{C}$. A step of UV irradiation on an aligner (SUSS MicroTecMJB4 Mask Aligner) was then carried out (Mode: First Exposure), using a designed mask (Selba, Versoix, Suisse) delimiting the surfaces of the future electrodes. A second annealing step was then carried out for 2 minutes at $125^{\circ} \mathrm{C}$, allowing the reticulation of the resin. A second UV exposure was performed on the aligner (Mode: Flood Exposure mode), for 30 seconds, without any mask to create a reverse polarity of the resin which then became negative. The substrates were immersed in a developer (AZ 726 MIF) for 30 seconds. Samples were rinsed with deionized water and dried with compressed air. ITO electrodes were then deposited on glass substrates by sputtering. A second platinum metallization was performed by hiding the central part of the electrodes, in order to increase the conductivity and to facilitate subsequent lateral connections. A lift-off step in an acetone bath was then carried out in order to remove the resin and to reveal the deposited metal. The annealing step of ITO semiconductor was essential in order to considerably increase the conductivity and the transparency of the raw deposit of ITO. This procedure was carried out in a conventional oven, able to reach a temperature of $300{ }^{\circ} \mathrm{C}$, in air and at atmospheric pressure. The oven was programmed in three steps; the first one was a linear $1 \mathrm{~h} 30$ temperature ramp from ambient temperature up to $300^{\circ} \mathrm{C}$, the second was a $300{ }^{\circ} \mathrm{C}$ temperature plateau of $3 \mathrm{~h} 30$ and the last one was a linear ramp down to ambient temperature. The electrical contacts were made using tin-plated copper wires. A circular well of PDMS $(3 \mathrm{~cm}$ in diameter and $1.5 \mathrm{~cm}$ in height), allowed defining the volume of solution necessary for cell culture. A rectangular shaped PDMS well (1 cm wide, $1.5 \mathrm{~cm}$ long and $0.5 \mathrm{~cm}$ high) delimited the active surface of the electrodes. The final device owned eight ITO electrodes (see Figure S2). Each ITO electrode was composed of one disk (diameter of $150 \mu \mathrm{m}$ with one $50 \mu \mathrm{m}$ width band to be connected to the sides of the sample) situated at $500 \mu \mathrm{m}$ far from the edge of the PDMS rectangle.

\section{Spectroscopic experiments}

Samples were placed in quartz cuvettes (Hellma) of 1x1 cm. UV/Vis absorption spectra were recorded on a Cary 300 spectrophotometer (Agilent Technologies, Santa Clara, CA) equipped with a $2 \times 2$ Sport dual cuvette holder (Quantum Northwest, Liberty Lake, WA) thermoregulated at $293 \mathrm{~K}$. Molar absorption coefficients were extracted using the linear relationship of the Beer- 
Lambert law. The evolution of the absorbance of FFN42 as a function of $\mathrm{pH}$ was measured between 3.57 and 11.05 in a Britton-Robinson buffer composed of $10 \mathrm{mM}$ of acetic acid, $10 \mathrm{mM}$ of CHES (2-(cyclohexylamino)ethanesulfonic acid) and $10 \mathrm{mM}$ of sodium dihydrogen phosphate in $50 \mathrm{mM}$ of $\mathrm{NaCl}$. The pKa values of the three protonation sites of FFN42 were extracted using SPECFIT/32 global analysis system (version 3.0 for 32-bit Windows systems). Fluorescence measurements were performed at $293 \mathrm{~K}$ with a QuantaMaster spectrophotometer (PTI, Monmouth Junction, NJ) equipped with a TLC50 cuvette holder (Quantum Northwest). In the case of the quantum yield determination of FFN42, solutions for emission measurements were adjusted to concentrations such that the maximum absorption was kept below 0.15 in the useful wavelength range. The overall emission quantum yields after one-photon excitation $\Phi_{\mathrm{em}}$ values were calculated from the following relation:

$$
\Phi_{\text {em }}=\Phi_{\text {ref }} \frac{1-10^{-A_{\text {ref }}^{\left(\lambda_{\text {exe }}\right)}}}{1-10^{-A\left(\lambda_{\text {exe }}\right)}} \frac{\mathrm{D}}{D_{\text {ref }}}\left(\frac{r_{i}}{r_{i_{\text {ref }}}}\right)^{2}
$$

where the subscript "ref" stands for standard samples, $A_{\text {ref }}{ }^{(\lambda e x e)}$ is the absorbance at the excitation wavelength, $\mathrm{D}$ is the integrated emission spectrum, and $r_{i}$ is the refractive index for the solvent. The uncertainty in the experimental value of $\Phi_{\mathrm{em}}$ of FFN42 was estimated to be $\pm 10 \%$. The standard fluorophore sample for the quantum yield measurements was quinine sulfate in $0.05 \mathrm{M}$ $\mathrm{H}_{2} \mathrm{SO}_{4}$ with $\Phi_{\text {ref }}=0.5$. ${ }^{[12]}$

\section{Electrochemical experiments}

All the voltammetric analyses of molecules on ITO and CFE were performed with an EA162 Picostat (eDAQ, Australia) through an e-corder 401 system associated with EChem software inside a Faraday cage. $\mathrm{Ag} / \mathrm{AgCl}$ wire was used as the reference electrode and the counter electrode was a Pt wire. The number of electrons for the oxidation of FFN42 was determined by means of two electrochemical methods. The steady state method was performed with a rotating disk electrode (RDE; glassy carbon electrode, diameter $3 \mathrm{~mm}$ ). The transient method was cyclic voltammetry (glassy carbon electrode, diameter $1 \mathrm{~mm}$ ). Both were recorded with a potentiostat EGG (Princeton Applied Research). They were performed in a solution of $75 \mu \mathrm{M}$ of FFN42 in PBS (pH 7.4) at two scan rates of 200 and $500 \mathrm{mV}^{-1}{ }^{-1}$ for cyclic voltammetry and at an angular 
rate equal to $5000 \mathrm{rpm}$ for $\mathrm{RDE}$ experiment. The reference electrode was a classical saturated calomel electrode (SCE) and the counter electrode was a Pt wire.

\section{Cell culture}

The BON cell line was derived from a metastatic human carcinoid tumor of the pancreas. BON N13 cells were provided by C.M. Townsend (University of Texas Medical Branch, Galveston, TX). The base medium for BON N13 cell line was DMEM/F12 (Dulbecco's modified eagle medium: nutrient mixture F-12). DMEM/ F-12 medium supplemented with $10 \%$ heat-inactivated fetal bovine serum as well as $1 \%$ penicillin/streptomycin solution was employed as complete growth medium filtered with $0.22 \mu \mathrm{m}$ filtration membrane before any use or experiments. BON N13 cells were maintained in complete growth medium in a $37{ }^{\circ} \mathrm{C}$ incubator with a humidified atmosphere of $5 \% \mathrm{CO}_{2}$. Cells were grown on $75 \mathrm{~cm}^{2}$ cell culture flasks (Nunc, Roskilde, Denmark) and culture medium was renewed every 2 days. Subculture of BON N13 cells were conducted weekly by trypsinization when cell confluence reaching approximately 90\%. After aspirating the culture medium out of the culture flask, confluent BON N13 cells were firstly rinsed twice with $5 \mathrm{~mL}$ sterile PBS solution in order to completely remove serum-containing culture medium which contained trypsin inhibitors. Then, $1 \mathrm{~mL}$ of trypsin-EDTA solution was employed to gently dissociate cells from the flask bottom. After being incubated in $37{ }^{\circ} \mathrm{C}$ incubator for during $3 \mathrm{~min}$, almost all the cells were detached from the flask bottom by trypsin treatment. In order inhibit the trypsin effect, the trypsinized cells were thus re-suspended in $9 \mathrm{~mL}$ fresh complete culture medium and were gently aspirated to dissociate all cell clusters into single cell. Finally, $1 \mathrm{~mL}$ cell suspension was added into a new culture flask with $18 \mathrm{~mL}$ fresh medium. PC12 cells were purchased from the American Type Culture Collection (Manassas, VA). The cells were maintained in RPMI-1640 media, supplemented with 10\% heated inactivated horse serum, $5 \%$ heated inactivated fetal bovine serum and $1 \%$ penicillin streptomycin solution (Life technologies) in a $5 \% \mathrm{CO}_{2}, 100 \%$ humidity atmosphere at $37{ }^{\circ} \mathrm{C}$. Cells were sub-cultured approximately every 4-5 days. Throughout the cell cultures lifetime, the medium was refreshed every 2 days. 


\section{Experiments on cells in the presence of FFN42}

For their observation under epifluorescence microscopy, cells were studied in Petri dishes or in ITO devices. These Petri dishes (P50G-1.5-14-F, MatTek Cultureware, Ashland, MA) or ITO devices were previously treated with a collagen IV solution $\left(0.1 \mathrm{mg} \cdot \mathrm{mL}^{-1}\right)$ before introducing the cells. $300 \mu \mathrm{L}$ of collagen IV solution was used to cover the whole surface of the substrate to enable a satisfactory adhesion of cells, allowing their optimal optical observation. Six hours after samples preparation, collagen solution was removed from the surface of the substrates, which were subsequently cleaned with a filtered solution of PBS ( $\mathrm{pH} 7.4)$. After the subculture stage (described above), cells were re-suspended in their complete growth medium. A dilution step of this high concentrated solution, allowed the acquisition of a final concentration within the sample of $10^{5}$ cells. $\mathrm{mL}^{-1}$. Finally, $4 \mathrm{~mL}$ are introduced into the different samples, previously treated with collagen IV solution. Samples are then maintained in the incubator (at $37{ }^{\circ} \mathrm{C}$ under an atmosphere of $5 \% \mathrm{CO}_{2}$ ), for a duration of 24 hours, before any experiments.

For the uptake and distribution of FFN42 in N13 and PC12 cells procedures, 24 hours after samples preparation, samples media were renewed, with complete growth media supplemented with various concentrations of FFN42 (10, 20 and $50 \mu \mathrm{M})$ and/or for different periods of time (20, 30 and $60 \mathrm{~min})$. Then, samples were stored in an incubator $\left(37^{\circ} \mathrm{C}\right.$ with a humidified atmosphere of $5 \% \mathrm{CO}_{2}$ ). Afterwards, Petri dishes were rinsed three times with filtered PBS (7.4) and cells were observed under epifluorescence in PBS for PC12 cells and in Locke's x1 for N13 cells.

For the tests of the toxicity of FFN42 in N13 cells, cell samples were prepared 24 hours before experiments. BON N13 cells were coated with a collagen IV solution $(0.1 \mathrm{mg} / \mathrm{mL})$ for a better cellular adhesion on Petri dishes (P50G-1.5-14-F, MatTekCultureware, Ashland, MA) with a concentration of 75000 cells. $\mathrm{mL}^{-1}$. Incubation of BON N13 cells were performed with the optimal conditions determined (20 $\mu \mathrm{M}$ of FFN42 during $20 \mathrm{~min}$ of incubation). The LIVE / DEAD-Thermofischer Scientific kit was used. Images of BON N13 cells were obtained under epifluorescence. The dead cells are characterized by a red coloration (Ethidium Homodimer-1, EthD-1, labeling). EthD-1 is a cell-impermeant viability indicator that has a high-affinity to nucleic acid with weak fluorescent until bound to DNA and then emits red fluorescence. It indicates the loss of the integrity of the plasma membrane. The living cells are characterized by a green coloration (Calcein AM labeling, to indicate intracellular esterase activity, sign of cell viability). 


\section{Electrochemical experiments on cells in the presence of FFN42}

Electrochemical measurements of exocytosis are nowadays a usual method. The experimental procedure was already described elsewhere (see ${ }^{[25 c]}$ as an example). Briefly, a microcapillary filled with a $10 \mu \mathrm{M}$ ionomycin solution was positioned against the cell of interest to initiate the exocytotic secretion (N13 cells previously incubated with FFN42 30 min at $20 \mu \mathrm{M}$ ). To perform amperometric measurement in Locke's X1 solution supplemented with $2.5 \mathrm{mM} \mathrm{CaCl}_{2}$ and 1.2 $\mathrm{mM} \mathrm{MgCl}$, a constant potential value of $+500 \mathrm{mV}$ vs. $\mathrm{Ag} / \mathrm{AgCl}$ (working as the reference electrode) was applied to a CFE working electrode (located at the top of the cell) by using a potentiostat AMU-130 (Radiometer). The resulting currents were recorded in real time and stored on a computer (e-corder 821, eDAQ converter; software eDAQ Chart; output digitized at $40 \mathrm{kHz}$ ). Amperometric traces obtained during cell secretion was visually inspected and signals were designated as exocytotic spikes if their maximum current values were 3 times higher than the rms noise of the baseline current recorded prior to each signal. Note that only well-isolated amperometric spikes were taken into consideration whereas those overlapped ones were discarded during data treatment. Each spike characteristics, i.e., the maximum oxidation current $\mathrm{I}_{\max }(\mathrm{pA})$, the total electrical charge $\mathrm{Q}(\mathrm{fC})$, the half-width $\mathrm{t}_{1 / 2}(\mathrm{~ms})$ were determined using homemade software. All values are reported as the mean \pm SEM of the data $\left(I_{\max } ; \mathrm{Q} ; \mathrm{t}_{1 / 2}\right)$.

\section{Conflict of interest}

There are no conflicts of interest to declare.

\section{Acknowledgements}

This work has been supported in part by Sorbonne Université, CNRS (UMR 8640), Ecole Normale Supérieure (PSL Research University), French Ministry of Research and Chinese Scolarship Council. M. G-C thanks "Emergences Ville de Paris 2014" Grant and Institut Universitaire de France Junior 2015 Fellowship Program. Marie-Aude Plamont and Dr. Lihui Hu are warmly thanked for their help in the discussions about cells culture and cells experiments, respectively. Jérôme Delacotte is also thanked for fruitful discussion. 


\section{Keywords}

electrochemistry, exocytosis, fluorescent false neurotransmitters, indium tin oxide, photophysics 


\section{Figures}

Figure 1

A)

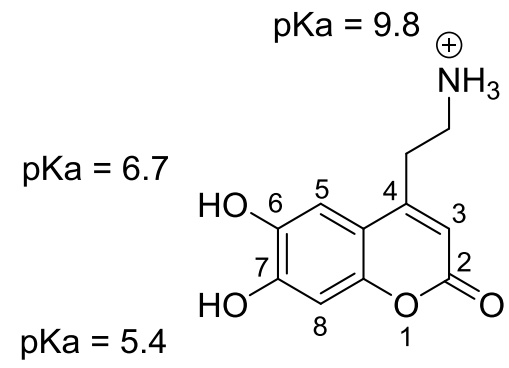

FFN42

B)

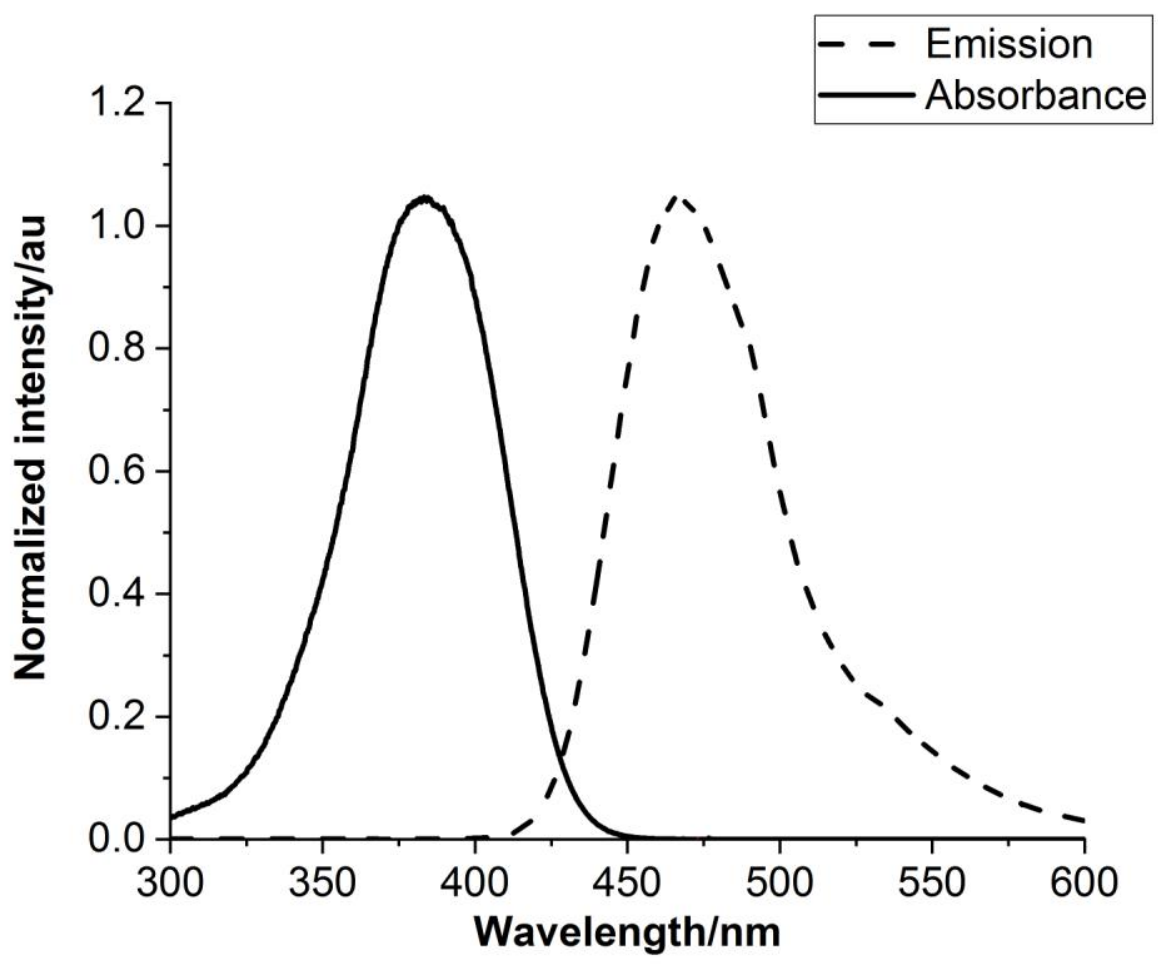


C)

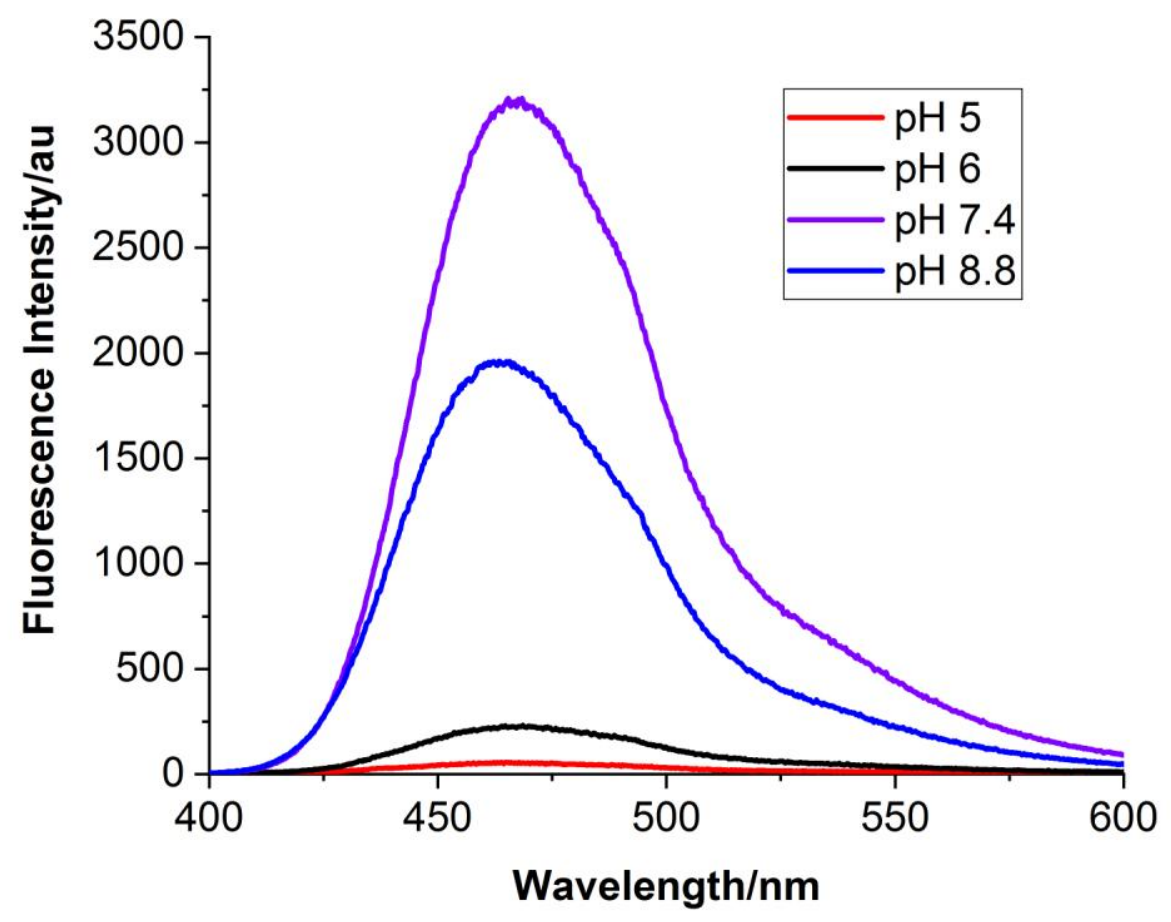


D)

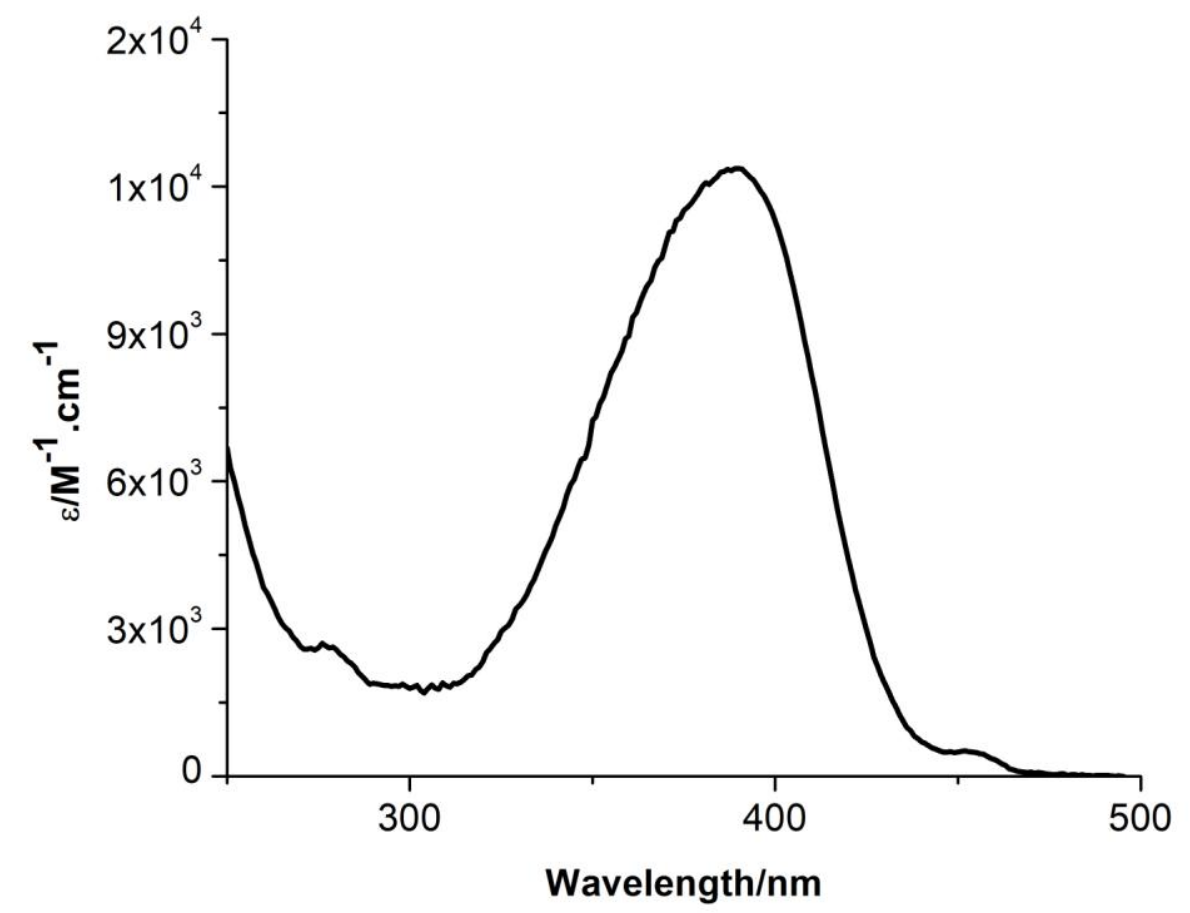


Figure 2

A)

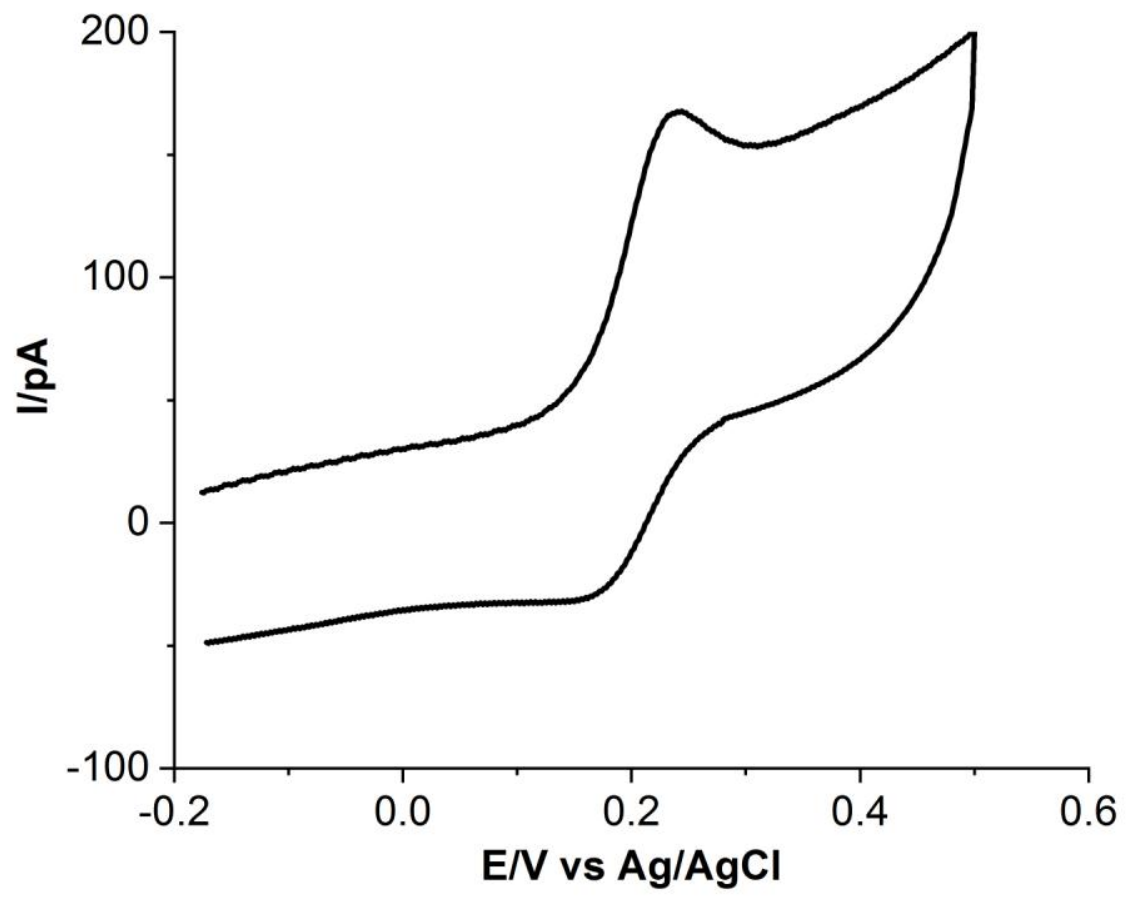


B)

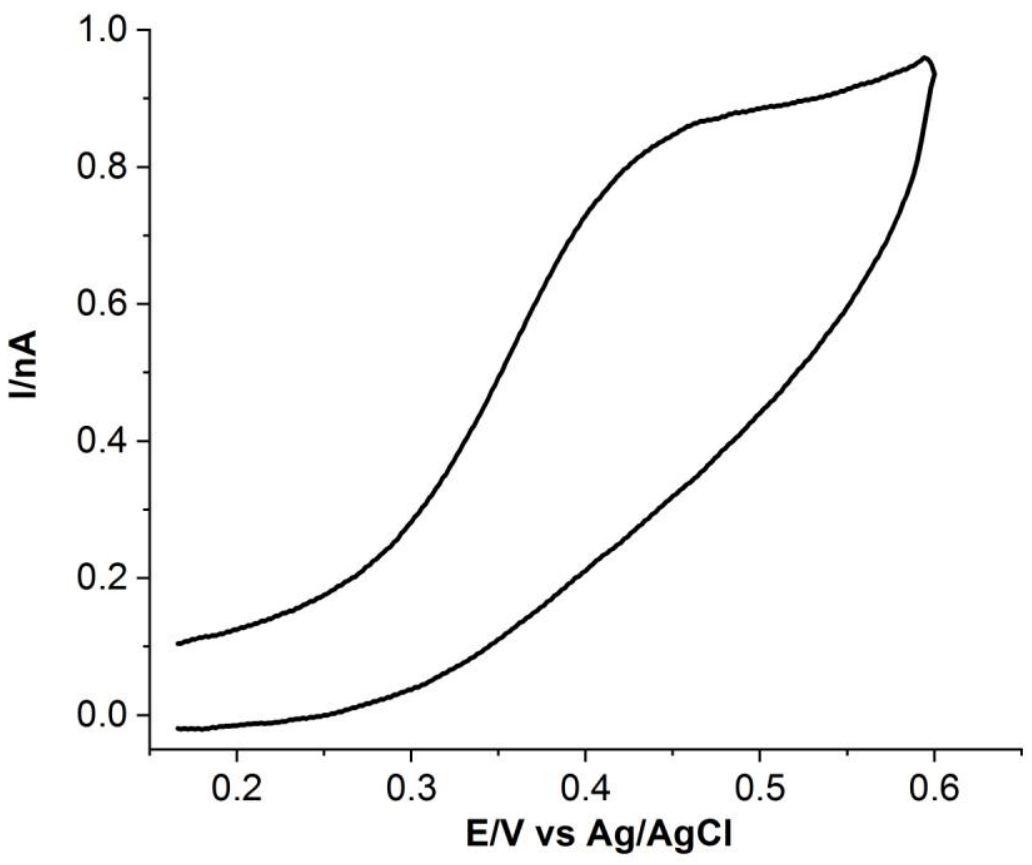


C)

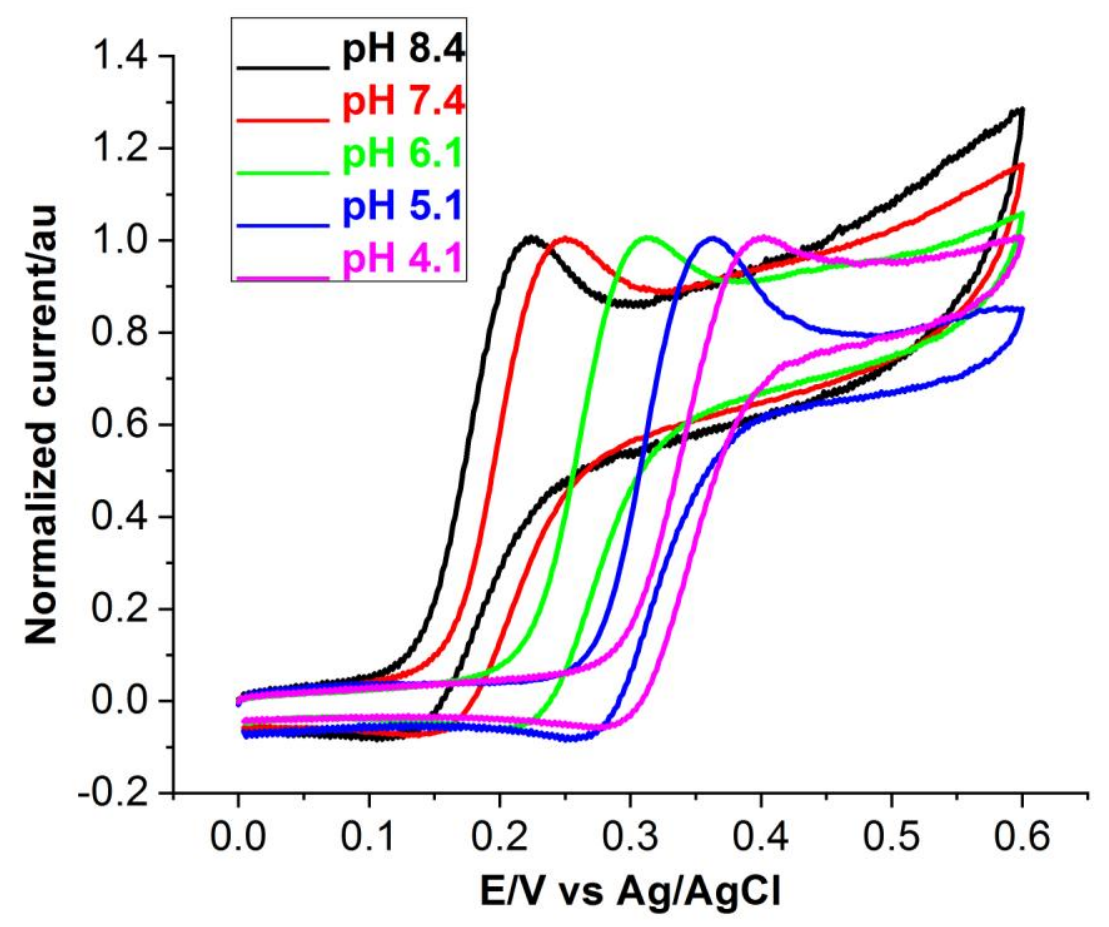


D)

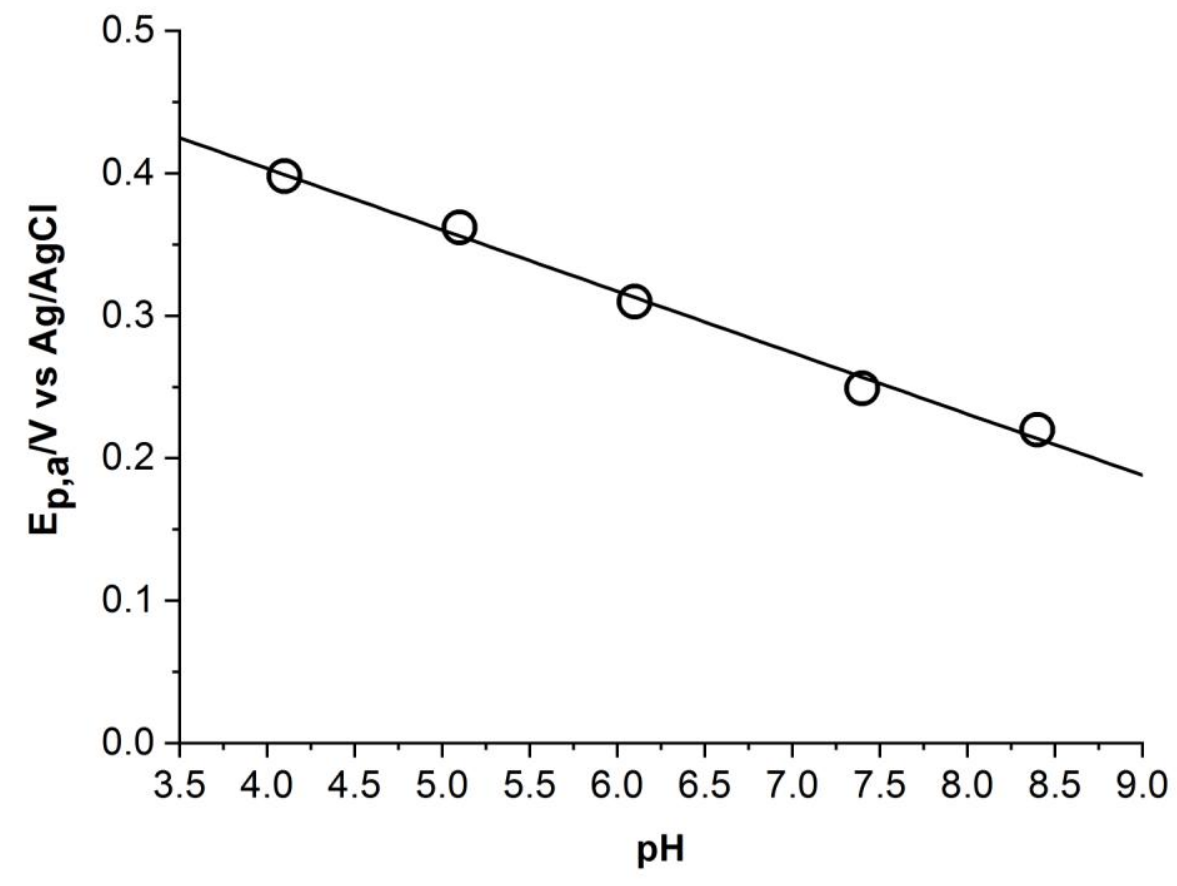


Figure 3
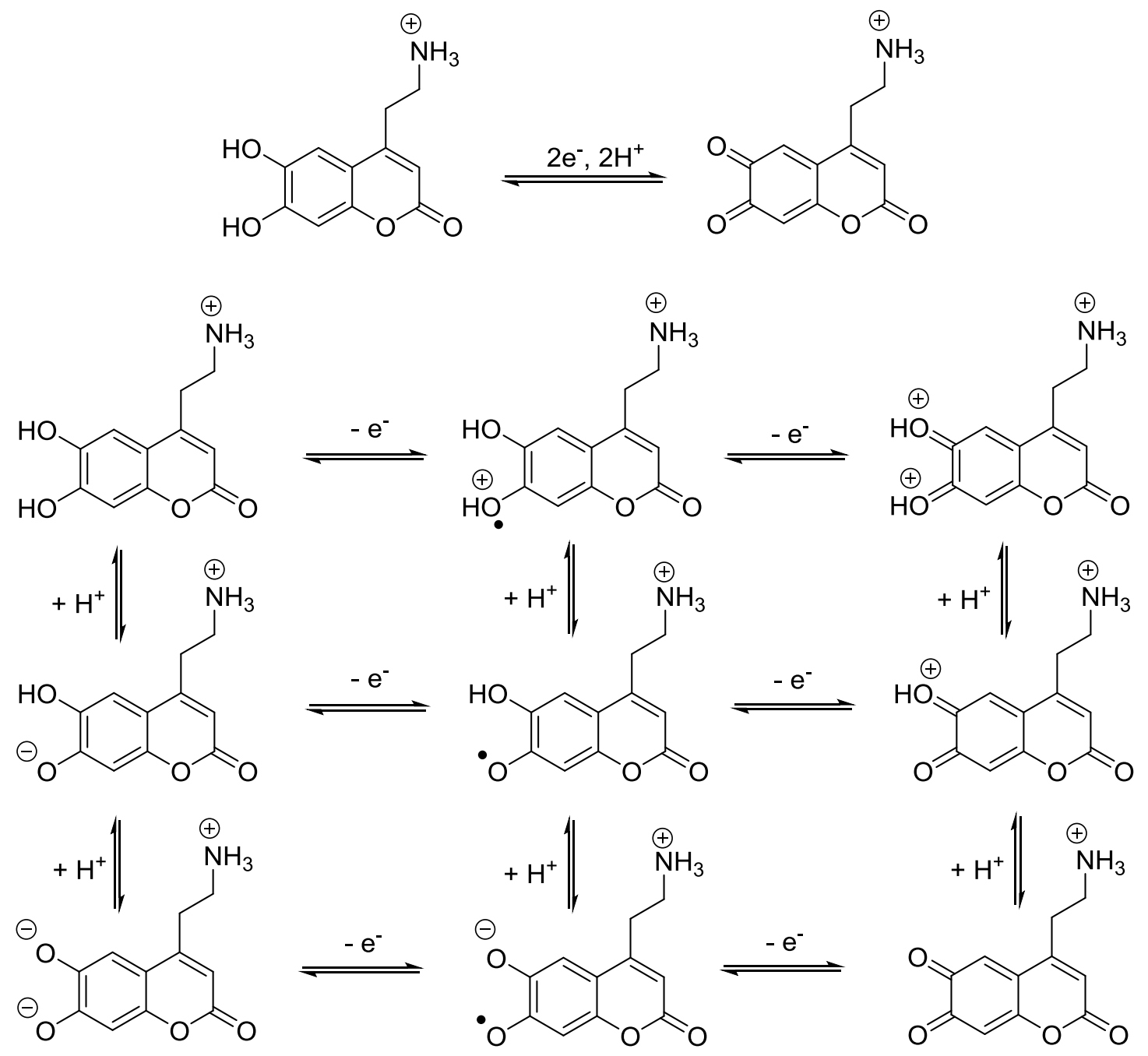
Figure 4

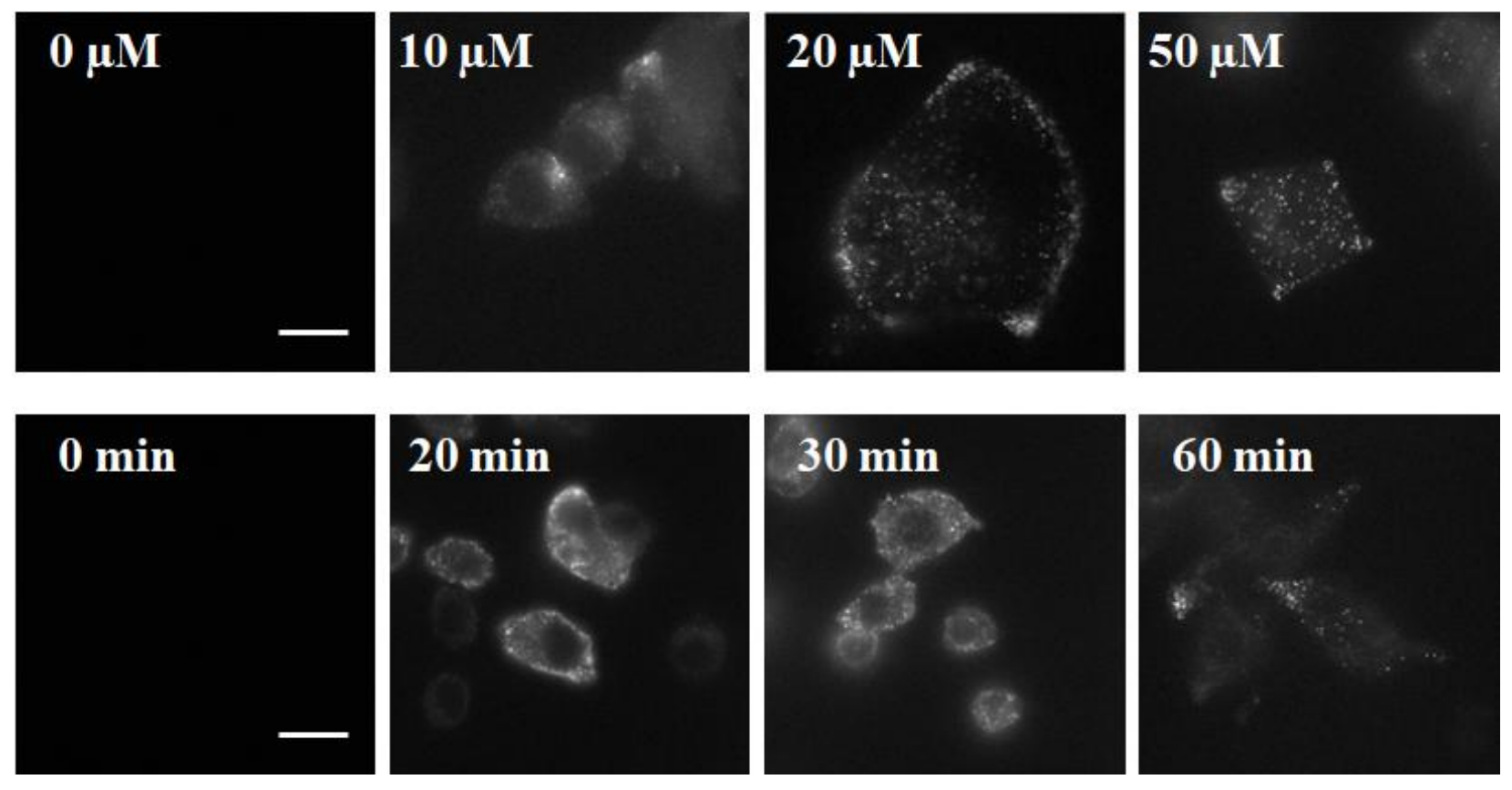


Figure 5
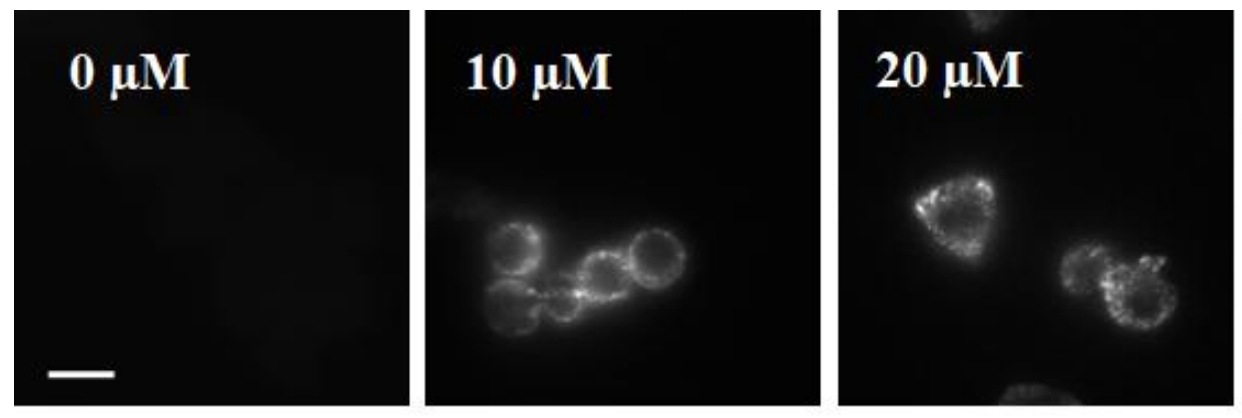

$50 \mu \mathrm{M}$
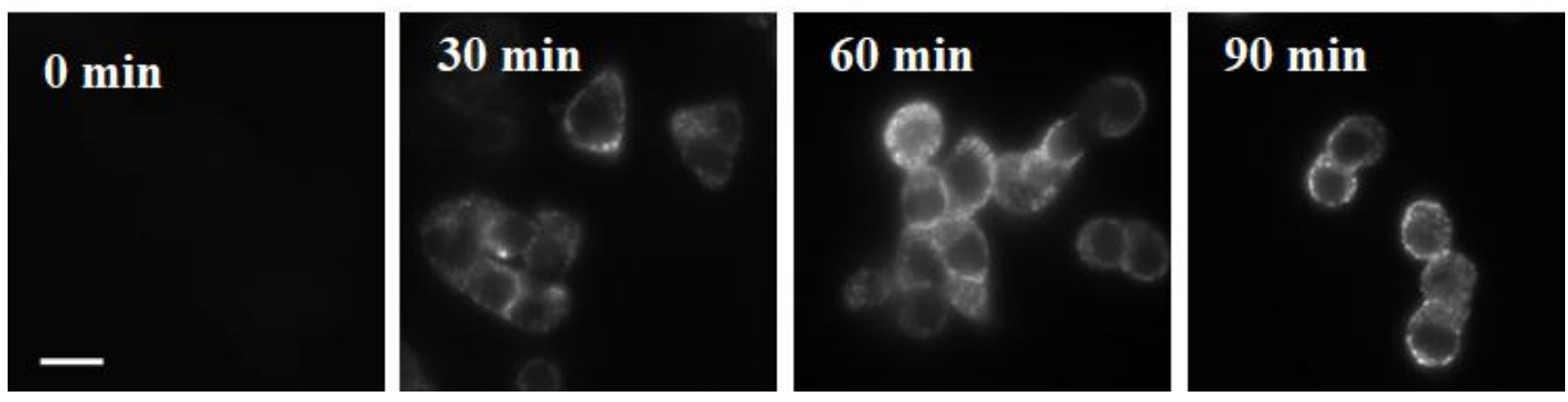
Figure 6

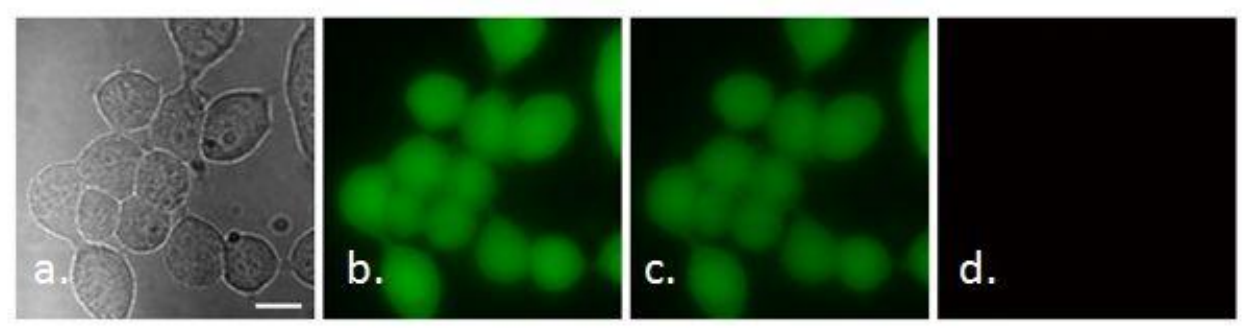


Figure 7

A)

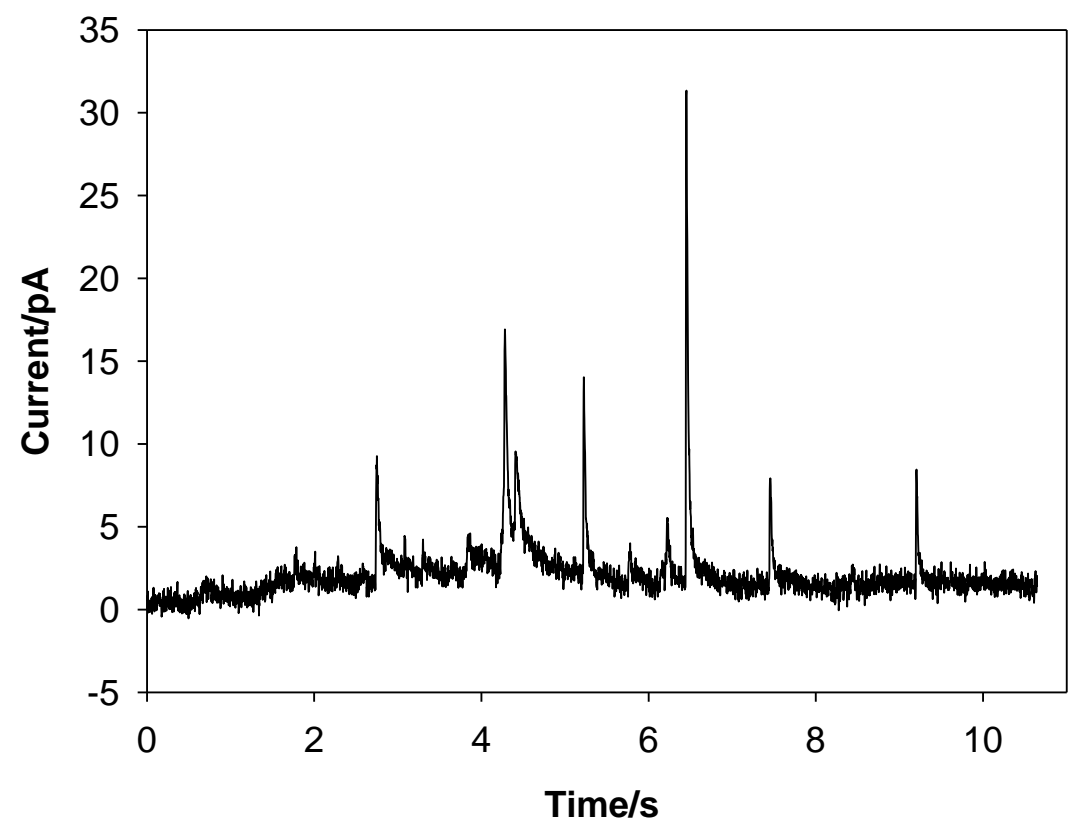

B)

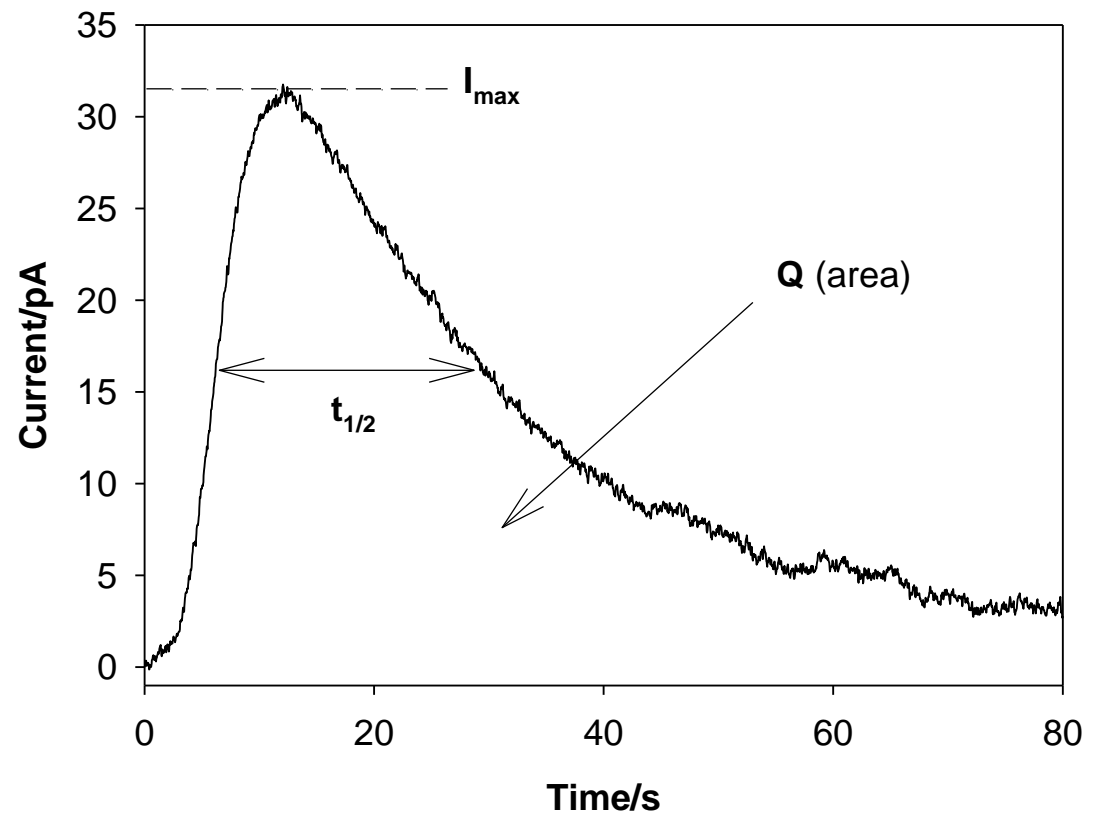




\section{Figures captions}

\section{Figure 1}

A) Chemical structure of FFN42 with the pKa values for the three acidic functions, obtained thanks to SPECFIT/32 global analysis system simulations on UV-vis spectra (see text). B) UVvis absorption and fluorescence emission spectra $\left(\lambda_{\mathrm{ex}}=380 \mathrm{~nm}\right.$ and $\left.\lambda_{\mathrm{em}}=470 \mathrm{~nm}\right)$ of FFN42 at $10 \mu \mathrm{M}$ in PBS (7.4). C) Fluorescence emission spectra of FFN42 at $10 \mu \mathrm{M}$ in PBS (7.4) at different $\mathrm{pH}$ values. D) Molar absorption coefficient $\varepsilon$ in $\mathrm{M}^{-1} \mathrm{~cm}^{-1}$ of FFN42 in a mixture of acetonitrile/phosphate buffer $(50 / 50 \mathrm{v} / \mathrm{v})$ without $\mathrm{NaCl}$ to prevent any aggregation of FFN42 and chloride ions.

\section{Figure 2}

Cyclic voltammogram of FFN42 $(100 \mu \mathrm{M})$ in PBS at pH $7.4\left(\right.$ scan rate $\left.=200 \mathrm{mVs}^{-1}\right)$ on CFE (A) and on ITO (B). (C) pH responsive normalized CVs of FFN42 $(100 \mu \mathrm{M})$ in PBS at $200 \mathrm{mV} \cdot \mathrm{s}^{-1}$ on CFE. (D) Oxidation peak potential as a function of $\mathrm{pH}$ for FFN42 $\left(\mathrm{E}_{\mathrm{p}, \mathrm{a}}=0.5757-0.0431 \mathrm{pH} ; \mathrm{R}^{2}\right.$ =0.99; data extracted from Figure 2C).

\section{Figure 3}

Proposed mechanism for oxidation of FFN42 based on reference ${ }^{[21]}$.

\section{Figure 4}

Epi-fluorescence images of N13 cells incubated with FFN42. Top: Incubation tests at different concentrations of FFN42 during $20 \mathrm{~min}$. Visible bright dots of the size of vesicles appeared at 20 $\mu \mathrm{M}$ concentration in FFN42. Bottom: Incubation tests at different time of incubation in presence of FFN42 at $20 \mu \mathrm{M}$. After 20 min of incubation fluorescence of vesicles was satisfactory. Scale bar: $10 \mu \mathrm{m}$.

\section{Figure 5}

Epi-fluorescence images of PC12 cells incubated with FFN42. Top: Incubation tests at different concentrations of FFN42 during $30 \mathrm{~min}$. Visible bright dots of the size of vesicles appeared clearly at $20 \mu \mathrm{M}$ concentration in FFN42. Bottom: Incubation tests at different time of incubation 
in presence of FFN42 at $20 \mu \mathrm{M}$. After $30 \mathrm{~min}$ of incubation fluorescence of vesicles was satisfactory. Scale bar: $10 \mu \mathrm{m}$.

\section{Figure 6}

Epifluorescence images of N13 cells in presence of $20 \mu \mathrm{M}$ of FFN42 during 20 min. Toxicity tests were performed with the LIVE/DEAD-Thermofischer kit. Green cells are living cells. Red cells are dead cells. a) Images in bright field. Fluorescence images with a b) green (GFP) filter, c) green and red (GFP/rhodamine) filters, d) red (rhodamine) filter. Scale bar: $10 \mu \mathrm{m}$.

\section{Figure 7}

A) Representative amperometric trace obtained after stimulation (10 $\mu \mathrm{M}$ ionomycin) of a single N13 BON cell preloaded with FFN42 (30 min at $20 \mu \mathrm{M})$. B) Isolated current spike with the three main extracted parameters $\left(\mathrm{t}_{1 / 2} ; \mathrm{I}_{\max }, \mathrm{Q}\right)$. 


\section{References}

[1] R. Jahn, T. C. Sudhof, Annu. Rev. Neurosci. 1994, 17, 219-246.

[2] a) J. A. Steyer, H. Horstmann, W. Almers, Nature 1997, 388, 474-478; b) N. Vardjan, J. Jorgacevski, R. Zorec, Neuroscientist 2013, 19, 160-174.

[3] C. Amatore, S. Arbault, M. Guille, F. Lemaitre, Chem. Rev. 2008, 108, 2585-2621.

[4] a) R. M. Wightman, J. A. Jankowski, R. T. Kennedy, K. T. Kawagoe, T. J. Schroeder, D. J. Leszczyszyn, J. A. Near, E. J. Diliberto, O. H. Viveros, Proc. Natl. Acad. Sci. USA 1991, 88, 10754-10758; b) R. M. Wightman, T. J. Schroeder, J. M. Finnegan, E. L. Ciolkowski, K. Pihel, Biophys. J. 1995, 68, 383-390.

[5] a) L. Zhang, X. A. Liu, K. D. Gillis, T. E. Glass, Angew. Chem. Int. Ed. 2019, 58, 7611-7614; b) A. Meunier, O. Jouannot, R. Fulcrand, I. Fanget, M. Bretou, E. Karatekin, S. Arbault, M. Guille, F. Darchen, F. Lemaitre, C. Amatore, Angew. Chem. Int. Ed. 2011, 50, 5081-5084; c) X. Liu, A. Savy, S. Maurin, L. Grimaud, F. Darchen, D. Quinton, E. Labbe, O. Buriez, J. Delacotte, F. Lemaitre, M. Guille-Collignon, Angew. Chem. Int. Ed. 2017, 56, 2366-2370; d) X. Liu, L. Hu, N. Pan, L. Grimaud, E. Labbe, O. Buriez, J. Delacotte, F. Lemaitre, M. Guille-Collignon, Biophys. Chem. 2018, 235, 48-55; e) K. D. Gillis, X. A. Liu, A. Marcantoni, V. Carabelli, Pflügers Arch. 2018, 470, 97-112.

[6] a) A. Meunier, R. Fulcrand, F. Darchen, M. G. Collignon, F. Lemaitre, C. Amatore, Biophys. Chem. 2012, 162, 14-21; b) A. Meunier, R. Fulcrand, F. Darchen, M. G. Collignon, F. Lemaitre, C. Amatore, Biophys. Chem. 2013, 171, 84-85.

[7] a) M. Lee, N. G. Gubernator, D. Sulzer, D. Sames, J. Am. Chem. Soc. 2010, 132, 8828-8830; b) P. C. Rodriguez, D. B. Pereira, A. Borgkvist, M. Y. Wong, C. Barnard, M. S. Sonders, H. Zhang, D. Sames, D. Sulzer, Proc. Natl. Acad. Sci. USA 2013, 110, 870-875; c) P. Merchant, D. Sulzer, D. Sames, Neuropharmacology 2015, 98, 90-94.

[8] L. Hu, A. Savy, L. Grimaud, M. Guille-Collignon, F. Lemaitre, C. Amatore, J. Delacotte, Biophys. Chem. 2019, 245, 1-5.

[9] L. Fournier, I. Aujard, T. Le Saux, S. Maurin, S. Beaupierre, J.-B. Baudin, L. Jullien, Chem. Eur. J. 2013, 19, 17494-17507.

[10] J. D. Keighron, A. G. Ewing, A.-S. Cans, Analyst 2012, 137, 1755-1763.

[11] M. Taniguchi, J. S. Lindsey, Photochem. Photobiol. 2018, 94, 290-327.

[12] A. M. Brouwer, Pure Appl. Chem. 2011, 83, 2213-2228.

[13] a) S. Charier, O. Ruel, J. B. Baudin, D. Alcor, J. F. Allemand, A. Meglio, L. Jullien, Angew. Chem. Int. Ed. 2004, 43, 4785-4788; b) S. Charier, O. Ruel, J. B. Baudin, D. Alcor, J. F. Allemand, A. Meglio, L. Jullien, B. Valeur, Chem. Eur. J. 2006, 12, 1097-1113.

[14] CRC Handbook of Chemistry and Physics, 81st Edition Edited by David R. Lide (National Institute of Standards and Technology). CRC Press: Boca Raton, FL, 2000.

[15] a) D. P. Manica, Y. Mitsumori, A. G. Ewing, Anal. Chem. 2003, 75, 4572-4577; b) A. N. Patel, P. R. Unwin, J. V. Macpherson, Phys. Chem. Chem. Phys. 2013, 15, 18085-18092; c) R. Trouillon, D. O'Hare, Electrochim. Acta 2010, 55, 6586-6595.

[16] C. Amatore, M. Azzabi, P. Calas, A. Jutand, C. Lefrou, Y. Rollin, J. Electroanal. Chem. 1990, 288, 45-63.

[17] A. J. Bard, L. R. Faulkner, Electrochemical Methods : Fundamentals and Applications, John Wiley \& Sons, 2001. 
[18] S. Sujaritvanichpong, K. Aoki, K. Tokuda, H. Matsuda, J. Electroanal. Chem. 1986, 198, 195-203.

[19] R. G. Compton, C. E. Banks, Understanding Voltammetry, 2nd Edition, 2011.

[20] K. Wedege, E. Drazevic, D. Konya, A. Bentien, Sci. Rep. 2016, 6.

[21] Q. Lin, Q. Li, C. Batchelor-McAuley, R. G. Compton, J. Phys. Chem. C 2015, 119, 1489-1495.

[22] a) B. M. Evers, J. I. N. Ishizuka, C. M. Townsend, J. C. Thompson, Ann. N.Y. Acad. Sci. 1994, 733, 393-406; b) V. S. Tran, S. Huet, I. Fanget, S. Cribier, J.-P. Henry, E. Karatekin, Eur. Biophys. J. 2007, 37, 55-69.

[23] M. Bretou, O. Jouannot, I. Fanget, P. Pierobon, N. Larochette, P. Gestraud, M. Guillon, V. Emiliani, S. Gasman, C. Desnos, A.-M. Lennon-Dumenil, F. Darchen, Mol. Biol. Cell 2014, 25, 3195-3209.

[24] a) Y. Gros, S. Schuldiner, J. Biol. Chem. 2010, 285, 5076-5084; b) J. Sun, J. Xu, N. J. Cairns, J. S. Perlmutter, R. H. Mach, Plos One 2012, 7, e49483.

[25] a) M. Holtje, B. von Jagow, I. Pahner, M. Lautenschlager, H. Hortnagl, B. Nurnberg, R. Jahn, G. Ahnert-Hilger, J. Neurosci. 2000, 20, 2131-2141; b) L. Kolby, P. Bernhardt, A. M. LevinJakobsen, V. Johanson, B. Wangberg, H. Ahlman, E. Forssell-Aronsson, O. Nilsson, Br. J. Cancer 2003, 89, 1383-1388; c) A. Meunier, M. Bretou, F. Darchen, M. Guille Collignon, F. Lemaître, C. Amatore, Electrochim. Acta 2014, 126, 74-80.

[26] R. H. S. Westerink, A. G. Ewing, Acta Physiol. 2008, 192, 273-285.

[27] S. Arbault, P. Pantano, J. A. Jankowski, M. Vuillaume, C. Amatore, Anal. Chem. 1995, 67, 33823390 . 